\title{
АКТУАЛЬНЫЕ ПРОБЛЕМЫ СОЦИАЛЬНОЙ СПРАВЕДЛИВОСТИ В ТВОРЧЕСТВЕ КИРГИЗСКИХ ПОЭТОВ-ГАСТАРБАЙТЕРОВ г. МОСКВЫ*
}

\begin{abstract}
Киргизские трудовые мигранты в России находятся в лучшем положении по сравнению с представителями других стран Средней Азии, как в плане обеспеченности более квалифицированной работой, так и в отношении сочиальной, культурной, языковой и т.д. интегрированности в российское общество. Эти обстоятельства не только дают части из них возможность заняться художественным творчеством (в стихах и в прозе), но и предоставляют больше шансов его реализовать в плане взаимодействия с российскими литературными организациями: немалая часть представителей киргизского мигрантского литературного клуба «Московские напевы» тесно взаимодействует с Союзом писателей России и другими литературными союзами, вплоть до членства в них. в работе рассмотрено творчество некоторых наиболее выдающихся творческих представителей киргизской диаспоры, посвящённое самым разным вопросам: не только и даже не столько проблемам самих мигрантов в России, но и многим актуальным социальным проблемам на родине, от домашнего насилия до урановых разработок и межэтнических конфликтов. Необходимо отметить при этом, что характер творчества киргизских поэтов постепенно меняется, особенно после получения киргизами-гастарбайтерами ряда льгот по сравнению с другими трудовыми мигрантами в 2018 г., от преобладания чисто мигрантских сюжетов к более общим вопросам социальной справедливости, в первую очередв в своей стране.
\end{abstract}

Ключевые слова. Киргизские мигранты, Москва, творчество, поэзия, соичиальная справедливость

Для цитирования: Ситнянский Г.Ю. Актуальные проблемы социальной справедливости в творчестве киргизских поэтов-гастарбайтеров г. Москвы // Вестник антропологии, 2021. № 4. С. 129-148.

Разным аспектам трудовой миграции киргизов в Россию посвящено очень много работ, исчисляемых, вероятно, сотнями, здесь мы упомянем лишь некоторые из них. Проблеме уделили внимание, например, Р. Аттокуров (Аттокуров 2009), А.Б. Веш-

Ситнянский Георгий Юрьевич - к.и.н., старший научный сотрудник Среднеазиатской группы Центра азиатско-тихоокеанских исследований, Институт этнологии и антропологии РАН (117334, Москва, Ленинский проспект, 32a). Эл. адрес: sitnyan@mail.ru

* Исследование выполнено при финансовой поддержке Филиала Фонда Розы Люксембург (ФРГ) в Российской Федерации по теме «Социальная справедливость в поэзии трудовых мигрантов из Центральной Азии в Москве» 
курова (Вешкурова 2011), Р.А. Маметов (Маметов 2009), Н. Мендибаев (Мендибаев 2012), Я. Сафонов (Сафонов 2008), Е.В. Тюрюканова (Тюрюканова 2009) и многие другие. Занимался этим вопросом и автор этих строк, наиболее крупная работа монография по миграциям (Ситнянский, Бушков 2016). Но творческая деятельность трудовых мигрантов - тема для меня принципиально новая, ни мне не приходилось этим заниматься, ни работы других авторов не попадались. Уже при первом погружении в тему становится очевидным, что в творчестве поэтов-мигрантов весьма сильны мотивы социальной справедливости, при этом с течением времени и с изменением положения киргизов в России (об этом ниже) эти мотивы несколько изменили своё содержание. Задача настоящей статьи - проследить развитие и эволюцию идейного наполнения творчества киргизских мигрантов. Работа выполнена в рамках гранта Фонда Розы Люксембург и основана как на личных контактах автора с поэтами-киргизами, так и на анализе сборников клуба киргизских поэтов «Москва кайрыктары» («Московские напевы»), предоставленных мне одним из учредителей клуба.

Началось киргизское мигрантское творчество с того, что с 2009 г. киргизская диаспора стала издавать общественно-информационную газету «Нур». Основной функцией газеты первоначально было информирование трудовых мигрантов о юридических услугах, например, публикация адресов посольства, консульства, юристов, к которым можно обратиться, а также клиник, кафе и т.д. Писалось в газете в своё время (20092010) и об опасностях, грозящих, например, от скинхедов. Все эти годы газета распространяется бесплатно, тиражом 10000 экземпляров. в период пандемии газета не выходила, теперь (данные на начало июня 2021 г.) возобновлено её издание.

По мере того, как издатели газеты «Нур» и другие руководители диаспоры начали собирать мигрантов, постепенно встречи переросли в том числе и в творческие вечера, на них стали привлекать занимающихся творчеством мигрантов, что и привело к концу 2010 г. к созданию клуба «Москва кайрыктары». К осени 2021 г. 20 членов клуба уже стали членами Союза писателей Киргизстана. Теперь члены клуба собираются ежемесячно, обсуждают и читают стихи, а раз в год организовывается конкурс поэтов. При этом, если первоначально такие собрания устраивались вокруг писателей и поэтов, приехавших из Киргизстана, то теперь в Москве много «своих» поэтов - мигрантов. Победителям конкурсов за счёт диаспоры обеспечиваются некоторые льготы, например, бесплатное лечение на год (сообщивший мне данную информацию руководитель клуба «Московские напевы» Б.Ш. Баланов сам уроженец Оша, по специальности врач-невролог, в Москве живёт с 2021 г., является также создателем и владельцем частной стоматологической клиники - кстати, ещё один пример того, как создаются рабочие места «для своих»; всего в Москве 25-30 киргизских клиник). в каждой области Киргизстана у клуба также есть координаторы, которые устраивают аналогичные творческие вечера и там. Многих начинающих поэтов клуб поддерживает чуть ли не с детства (среди тех, кто публикуется в сборниках клуба, немало совсем молодых), т.к. новички поначалу никому не интересны.

Всего с 2010 г. членами клуба побывали в разное время примерно 1000 человек. в декабре 2020 г. в Ресурсном центре Москвы (Рязанский проспект) состоялся вечер, посвящённый десятой годовщине «Московских напевов», с участием представителей посольства Киргизской Республики. А на 2022 или 2023 год клуб запланировал проведение в Бишкеке курултая всех, кто когда-либо был его членом. 
Представляется целесообразным рассмотреть творчество некоторых членов клуба «Москва кайрыктары» в динамике и в развитии. Начну с ранних работ, в большей мере затрагивающих именно мигрантские проблемы.

Насырова Самара Бакировна, из Оша, живёт в России с 2000 г. Прошла долгий трудовой путь (начала с дворника). Стихи пишет с детства. По образованию биолог, но считает это ошибкой («надо было на журналиста учиться»). в газете «Нур» имеет свою рубрику «Судьба», посвящённую женщинам-мигрантам. Автор пяти книг (в стихах и прозе). На её творчестве явно отразились проблемы первых лет пребывния в России, когда киргизам часто приходилось несладко. Вот одно из её стихотворений.

Муздак калаа

Жат жерден жардылыкка издеп дабаа, Келгенде тосуп алган... муздак калаа. Жыл сайын кетем деймин... бирок кетпей, Жүрөктүн түпкүрүнөн сыздайт жара...

Шум кабар, ар күн сайын укканыбыз, Шуулдаган метро болуп чыкканыбыз. Өмүрлөр согушу жок кырылууда, Ушулбу тагдырды биз утканыбыз?...

Жетишпей бул турмушка көрк берүүгө, Чырактай кайран кыздар өрттөнүүдө. Айдалып Сахарово тор ичинде, Алты айлап кыргыз күнүн өткөрүүдө.

Жигиттер кулап, өлүп майып болду, Дайынсыз канча жандар кайып болду. Оор жумуш очорултуп эчендерди, Аттиңай, кыз келиндер айып болду...

Көксөгөн мал мүлкүмдү топтоптурмун, Эмгекчил кумурскага окшоптурмун. Мекенден сыртта жүрүп кусаланган, Ден соолук жаштыгымды жоктоп турдум.

\section{Холодная башня}

В странной земле ищу исцеления, Холодная столица приветствует по прибытии. Каждый год я покидаю её, но не хочу Сердце разрывается от боли.

Быстрые перекусы, ежедневные новости, Поездки в шумном метро.

Вымирание без войны -

Это наша жизнь?

Не хватает красоты в этой жизни, Сгорает свеча, сгорают девушки, Загнали нас в Сахарово, По шесть месяцев киргиз тут проводит.

Молодые люди становились инвалидами, Падали и умирали.

Сколько пропало без вести! От тяжёлой рботы тускнут глаза, Сколько девушек оштрафовано!

Я накопил желанное имущество, Работая как трудолюбивый муравей. Но плохо мне за пределами родины, У меня не было молодости и здоровья.

О тяжёлой жизни вдали от родины пишет и Дамир Абсатаров, 1989 г.р., уроженец Ноокатского района Ошской области в стихотворении «Дневник мигранта». Окончив в 2012 г. Бишкекскую академию художников-дизайнеров им. Т. Садыкова, Д. Абсатаров трудится в Москве. Как и другие мигранты, он «встаёт ни свет, ни заря, чтобы работать весь день» (Москва кайрыктары-5 2016: 151-152; в связи с отсутствием некоторых киргизских букв они здесь и далее заменены русскими, за исключением тех случаев, когда компьютерный текст передан автору в том числе и на киргизском языке). 


\section{Мигранттын кундолугу}

Кунуго кором кочодо турун мигранттын, Кылганы бар, ылгабай баарын кызматтын. Акча деп жургон ушунча элдин ичинде,

Ырыскы издеп журомун, мен да мигрантмын. Ар тандан туруп барганы бир жол мигранттын, Кечке тейин иштеп, конулун алат бир баштын

Тугонбос ошол, кок кагаз учун омурдун

Арнаган элдер ичинде, мен да мигрантмын! Дайыма супсак, кундору окшош мигранттын,

Тилекке каршы корбодук балын бул жаштын.

А бирок дайым, бир умут менен журомун, Кудайдан кутом, бугунчо ишмер мигрантмын!

Ботондон гана жарыйбы куну мигранттын? Жыргатып кээдэ Россия копту ыйлаттын. Элимдин эмес, урматтап башканын салтын, Кыйраты иштеп, жеринде журом мигрантмын!

Жер кезип ойноп, татышып жашоонун кантын, Жургондорго таныркап кээдэ сук арттым. Спортчу, ырчы, турист да болсом жарашмак, А бирок азыр турист эмес, мигрантмын!

\section{Дневник мигранта}

Ежедневно вижу на улице стоящего мигранта,

Какая работа есть, то и ладно.

Стольким людям, говорят, важны деньги, Я ищу пропитание, и я тоже мигрант.

Мигрант, который встаёт ни свет, ни заря, Чтобы работать весь день.

Безгранично значение для жизни синей бумажки (мигрантского документа - Г.С.),

Среди людей, выбравших это, я тоже мигрант!

В дни миграции вы постоянно скучаете,

К сожалению, мы не видели сладость молодости.

Но всегда с надеждой,

От Бога жду [хорошего], сегодня я работник-мигрант!

Разве это участь только мигранта?

Россия больше плачет, чем вздыхает.

Уважайте чужие традиции, а не свои,

Я - мигрант, идущий по разрушенной земле! Как же получать радость от жизни, путешествуя по земле,

Как же жить в мире и согласии.

Если бы я был туристом, это было бы прекрасно,

Но теперь я не турист, я мигрант!

Мухамбет Каныбек уулу, 1992 г.р., из Кара-Кульджинского района Ошской области. Мухамбет - технический редактор «Москва кайрыктары», а также автор книги «Утренний луч» (Москва кайрыктары-5 2016: 249-250), одно из своих стихотворений посвятил проблемам мигрантов в общении с ФМС. Вероятно, оно написано значительно раньше года публикации сборника (2016), хотя бы потому, что полиция там названа милицией.

\section{Жарма жана ФМС}

Карегемде апакдемин жамалы, Кайнап турат казанында тамагы. Даамы таттуу тилимден эч тушпогон,

Эске тушту балалыгым баягы. Ботон элдин жеринде конок болуп, Даам жутпадым апакдемин тамыгындай, Жакшы-жаман кундор отту жомок болуп,

\section{Крупа и ФМС}

И в этот день, как говорится, Ничто не предвещало.

$\mathrm{He}$ выходил из памяти вкус сладкого ломтика,

Вспоминалось мне детство.

Как гость в чужих краях, 
Кыш чилденин согуп откон шамалындай. Бир батирди он беш адам ээлегенбиз, Ашканда алты казан кайнап турат. Ары чыгып кайрылып кирген сайын,

Акырындап милициялар кайнап турат.

Апакемдин тамагынын даамын энсеп, Жарма кылдым кууруп алып унду эптеп.

Муздаганча терезеге койгон кезде,

Милициялар кирип келди «выходим» деп, Мигранттын туйшугу коп башындагы, Ачуум кайнайт барыш кетпей кашымдагы. Тор ичинде олтурабыз топтолушуп, Камап салган карыларын, жашын дагы. Курсак сылайт ачып калса карындары, Убакыт, саат созулуп ага берди.

А менинчи жарма турат оюмдагы, Уурталбастан терезеде кала берди.
Не глотал, жевал как жвачку.

Хорошие и плохие дни прошли, как сон,

Как зимний ветер.

Пятнадцать человек в одной квартире, На плите кипят шесть кастрюль.

Каждый раз, когда вы уходите и возвращаетесь, Постепенно милиция начинает сердиться (букв. «закипает»).

Тоска по еде, приготовленной мамой, Крупу мелко нарезать (раздробить?) и обжарить. Потом поставить на подоконник до остывания. Милиция вошли и сказала «выходим»,

На плечах мигранта много проблем, Я не знаю, что делать дальше.

Старых и молодых

Заперли в «обезьянник».

Живот потёр, живот успокоился,

Время шло.

А я оставался в думах

О крупе на окне.

Ещё одно стихотворение сходного содержания написала Перизат Абдыкасымова, 1996 г.р., уроженка Тюпского района Иссык-Кульской области, занявшая третье место на конкурсе поэтов 24 апреля 2021 г., на котором мне довелось присутствовать. После окончания юридического факультета Каракольского университета она работает в Москве (Москва кайрыктары-5 2016: 291).

\section{Мигранттык кундор}

Бакыт издеп алыс-алыс жактардан, Кыйын болду кобунчосу жаштарга. Мезгил отуп, кун кечкирип-тан атып, Адал иштеп эмгек кылып жашайбыз.

Тууган-урук, уй-булоодон чектелип, Бозоргондой нур жузбуз кезерип. Оз жеринен ала албай мээримди, Биз жашоону ботон жерден издедик. Тагдыр бизди сынадыбы билбеймин, Кайырчыдай кочо таптап иштедик. Биз жашоону ботон жерден издедик. Тагдыр бизди сынадыбы билбеймин, Кайырчыдай кочо таптап иштедик.

Кайгы салып журокторду муздатып,

Кенен жатып, ысык тамак ичпедик. Четте журуу абдан кыйын билсениз, Журок сыздайт, коздогу жаш термелип.

\section{Мигрантские дни}

В поисках счастья в далёких краях

Трудно было многим молодым.

Время идёт,

И мы живём честным трудом от рассвета до заката. Мы думаем о долге перед семьями, И на наших лицах эта забота отражается.

Любовь, которую мы не могли получить на своей земле, Мы искали в чужой стране.

Я не знаю, бросила ли нас судьба,

Мы работали, как нищие, стуча по улицам.

Мы лежали широко (?), не ели горячей пищи, Охлаждая сердца от горя.

Вы знаете, очень трудно оставаться равнодушным, Сердце бьётся, слёзы подступают к глазам.

Сколько судеб разбито,

Здоровье уходит.

Редкий день без суеты, Работать в Москве скучно.

Но как бы я ни был разочарован и ни скучал,

Я считаю свою судьбу правильной. 
Кенен жатып, ысык тамак ичпедик.

Четте журуу абдан кыйын билсениз,

Журок сыздайт, коздогу жаш термелип.

Талкаланып канчалаган тагдырлар, Ден-соолуктар кетип жатат тепселип.

Кыйын кундун кыйынына каржалбай, Иштеп келем Москвада тажабай.

Конул калып, канча тажап турсам да,

Оз бактыма туура карайм жалтанбай.

Эх, мигранттык кундор кандай кусалык, Мекениме суйуум кучойт такшалып.

Оз жеримде мумкунчулук жок болсо,

Айткалачы, кандай ала кылабыз?

А вот такое стихотворение вышло из-под пера Мээрим Арапбаевны Арыновой, 1992 г.р., из Кара-Сууского района Ошской области; кроме того, в том же 2016 г. эта поэтесса издала сборник стихов и прозы «Жан Сырым» («Секрет души») (Москва кайрыктары-6 2016: 41).

\section{Мигрант ыры}

Алыстап келип айылдан дагы, башкадан

Журобуз иштеп каражат тартыш айынан. Ай сайын иштеп акчага колун жетээрде,
Эх, как тоскливы дни мигранта,

Любовь к родине крепнет и становится более возвышенной.

Скажите, если у меня нет возможностей на своей земле,

Как мы можем это изменить?

Айлыгын бербей кур жанды абдан кыйныган. Пропускаете зарплату и очень расстраиваетесь. Чалышаат уйдон «акчанды салчы, керек» деп, Часто из дома звонят, говорят: «Шли деньги»,

Ойлошпойт алар, акчны кайдан келет деп. Они не думают, откуда деньги берутся.

Ооматын келет иштесен жакшы айлыкка,

Жалкоорок болсон бир сом пул бекер беришпейт.

Кубарып жузу иш ордун таппай кыйналган, Ар ишке барып арандан зорго жан бакан. Ар айда келчу жашаган жерге толо деп,

Если ты работаешь хорошо, тебе платят хорошую зарплату,

Если ты ленивый, тебе не дадут ни копейки.

С измученным лицом, нашёл наконец работу,

Каждый день ходит на работу, едва сводя концы с концами.

Бир тыйын таппай таарынып алсыз ыйлаган. Не найдя ни копейки, горько плакала от обиды, Кордугун коргон жашынан тартып улуусу, Что каждый месяц было полно желающих.

Тил билбей келип турмушту женил корушу. Старшие по возрасту видели оскорбления,

Айла жок барган женил жол акча табууга, Их легко увидеть, не зная языка.

Октунот аттин, кыздардын «тиру олуусу».

Коодонго батпай кокурок толуп ыйлады,

Корсом бир гана кыйналган кыргыз жаранды.

Оюмдан онго болунуп кетем заматта, Турмуштун кандай талабын билсен, айтсанчы? Коодонго батпай журогум сыздап кыйналат, Ар куну корсом кыйналган кыргыз жаранды.

Хитрый путь, легкий путь к зарабатыванию денег, Смелый путь к «выживанию» девушек.

Плач наполнял грудь, не смещаясь в тело,

Я видел только пострадавшего киргизстанца.

В какой момент ты узнаешь,

Чего требует жизнь?

Моё сердце болит, не вмещаясь в тело:

Каждый день я вижу страдающего гражданина Киргизстана. 
Поднимаются в стихах и такие проблемы, как смерть соотечественников на чужбине. Та же С.Б. Насырова предваряет стихотворение «Болезнь языка» (тоже явно произведение более ранних лет) такими словами: «Два-три дня назад мой земляк, живущий на одной из сельских улиц, работал на стройке и умер, ему упал кирпич на голову...Из Москвы в год уезжают две, три сотни гробов. Сумасшедшая проблема!»

\section{Дил оору}

Жаным кейип, бүт дилим ооруп турат, Жаштар өлүп, кырсыгы тооруп турат. Жандай көргөн баласын таппай калып, Жашын төккөн энелер соолуп турат.

Калктын саны күн санап азайууда, Карылары көк кийип азалуу да.

Кайран кыргыз кул болдук бөтөндөргө, Качан деги жетебиз тазарууга?...

Орустардын колунан өлүп жатат, Орустардын кордугун көрүп жатат. Оозун ачып, каяша кайтаралбайт, Орустарың кыргызды сөгүп жатат.

Качан келет кайтаар күн элибизге, Кагылайын, бейиштей жерибизге. Канды соруп, башкалар айлантпасын, Маңкурттукту, жамабай терибизге.

Жаштарыбыз жаш туруп өлбөсүнчү, Жамандыкты эч качан көрбөсүнчү. Жаш жубайлар көбөйүп, өмүр сүрүп, Жаз алдында келиндер төлдөсүнчү...

\section{Болезнь языка}

Душа болит, вся душа болит, Молодые умирают, беда наступает, Не встретив ребёнка живым, У матери все слёзы высыхают.

Число народа сокращается, Старики тоже одеты в синее (?). Киргизы стали рабами чужих. Когда мы сможем наконец очиститься?

Он умирает от рук россиян, Он видит унижение от россиян. Что значит открыть рот

Там, где нет возврата?

Когда придёт день вернуться домой?

Давайте вернёмся в нашу землю, Никому не позволим сосать кровь, Не будем манкуртами.

Пусть наша молодёжь не умрёт молодой, Пусть никогда не увидит зла.

Пусть молодые пары живут долго, Пусть весной невесты будут счастливы...

Вместе с тем, мигранты, судя по содержанию некоторых стихотворений, не теряют надежды, что не ограничатся обустройством России, но смогут преобразовать и свою страну. Уже цитированный выше Мухамбет Каныбек уулу написал, как он «утро встречает с мыслью, что впереди много разных дел, чтобы красиво украсить Ош, Бишкек и семь областей Киргизстана» (Москва кайрыктары-5 2016: 250-251).

\section{Мигрант ыры}

Жалындаган жыйырмадагы курактабыз, Жашыбыздан оз мекенден узактабыз. Жарышып иштин баарын бутуруп, Жаныртып жат олкону баратабыз.

Куулонуп кучко толгон убактабыз,

Куйунуп туркун ишке байланабыз. Колдорубуз ылай-баткак болгон менен, Кооздоруп бара жатат айланабыз. Ойлогон максаттар коп алдыдагы, Ой менен тосуп келем аткан танды. Ойдогудай кооздоп алсак экен деп, Ош, Бишкекти, жети дубан Кыргызстанды.

\section{Песня мигранта}

Нам за двадцать,

Мы старше нашей родины.

Мы едем в чужую страну,

Чтобы завершить срочную работу.

В этот день, когда мы полны сил и энергии,

Мы готовы к любой работе.

Наши руки были в грязи,

Но всё вокруг становится всё красивее.

Утро встречали с мыслью,

Что впереди много разных дел.

Чтобы красиво украсить

Ош, Бишкек, семь областей Киргизстана. 
Поэт-профессионал из числа мигрантов, уже упомянутая С.Б. Насырова в стихотворении «Мы в чужой стране» пишет на ту же тему (приводится частично). Она призывает не забывать свою Родину и мечтает вернуться домой.

\section{Бөтөн элде жүрөбүз}

Мындай жашоо жазылыптыр тагдырга, Муңайбастан баарын жеңип алдыга.

Өз мекенге эсен аман кайталы,

Өлкөбүзгө салым кошуп талпына.

Султан болуп бөтөн жерде жүргөнчө, Суу ичсек да, ултан болуп өз жерде.

Сурап алаар эч кими жок жетимдей, Сустаябыз бөтөн элде кез кезде...

Чөнтөгүбүз акчасына толсо да, Чөйчөгүбүз нак алтындан болсо да.

Унутпайлы Туулган жерди мекенди,

Урмат сыйы бакыт кушу консо да.

\section{Мы в чужой стране}

Такая жизнь начертна судьбой, Без нефти всё впереди.

Давайте благополучно вернёмся домой, Сделаем что-то для страны.

Чем быть султаном в чужой стране, Лучше быть подмёткой на своей земле.

Как сирота, у которого ничего нет, Суетимся на чужбине.

Даже если наши карманы полны денег И наши чашки из чистого золота, Давайте не будем забывать родину, И пусть счастье не кончится.

Есть среди поэтов-мигрантов и другие профессионалы. Айнура Бекбосыновна Бекболотова, 1969 г.р., уроженка Иссык-Кульской области, в России постоянно живёт в России с декабря 2015 г. в 1990-х гг. окончила Всесоюзный заочный институт пищевой промышленности, в Москве А.Б. Бекболотова работала пять лет в школе заведующей столовой, а весной 2020 г. ушла оттуда, потому что поступила на вечерние литературные курсы им. Горького. Здесь сказалась и наследственность: её мама - поэтесса, она с молодости писала стихи, например, о детстве, о послевоенных годах (она 1944 г.р.). При этом она писала «для себя», издавать стихи не собиралась, сборники опубликовала (и теперь готовит к печати четвёртый том) её дочь. Сама Айнура Бекбосыновна первые стихи написала в 15 лет. в её творчестве (в данной статье использованы работы более поздние) уже сказались те изменения, которые произошли в положении киргизов в России в последние годы. Представляется нужным кратко их перечислить.

В 2018 г., в статье, посвящённой некоторым проблемам киргизских трудовых мигрантов в Москве и Подмосковье «Киргизы в России - «как дома» или «почти как дома»?», я писал, что киргизы в России находятся в более выгодном положении, чем представители некоторых других среднеазиатских стран (Ситнянский 2018), сегодня киргизам больше платят, и работодатели отдают приоритет работникам киргизам (Перспективы 2017). Эти сведения подтверждаются и моими собственными наблюдениями в других регионах России в 2006-2011 гг. - в Саратовской, Пензенской, Оренбургской, Самарской, Омской, Тюменской, Московской областях. Подтверждают их и материалы проведённого мною летом-осенью 2018 г. обследования среди киргизов Москвы и области: лишь 7\% опрошенных, например, жаловались на задержку зарплаты. в частности, Представительство Государственной службы миграции при Правительстве Киргизской Республики в Российской Федерации, как и другие организации, по мере своих возможностей помогают мигрантам в отстаивании права на своевременную оплату труда (Ситнянский 2018: 87). 
Ещё одна причина более выгодного положения киргизов по сравнению с выходцами из других стран Региона - то, что в последнее время в диаспоре наметилась тенденция создавать рабочие места для своих - выходцы из Киргизстана открывают в России своё дело и дают работу землякам. «В середине нулевых (2000-х - Г.С.) в Москве такого ещё не было, чтобы киргиз работал на себя», - констатирует один из информантов (Киргизы Москвы 2017). Более того: киргизы более тесно, чем представители других стран региона, интегрированы в жизнь России. Согласно изменениям и дополнениям к Договору о вступлении Киргизстана ЕАЭС (август 2018 г.), киргизы получили право требовать от работодателя записи о приеме на работу в трудовую книжку. «Работа в России будет засчитываться в общий трудовой стаж, а члены семей получат право претендовать на социальные обеспечение: бесплатную медицину, места в детских садах, школах и вузах России (Почему киргизы...). Это породило снижение числа желающих закрепиться в России на ПМЖ. в 2018 г. более $72 \%$ семейных и 75\% холостых киргизов предполагали вернуться в свою страну, в основном через 1-5 лет, лишь единицы называли большие сроки (максимальный - 10 лет), чуть более $20 \%$ планировали периодически приезжать на работу и только 6-7\% - закрепиться в России и постоянно жить. На момент проведения опроса (2018 г.) постоянно жили в России 9,4\% опрошенных (Ситнянский 2018: 89); для сравнения, ещё в 2007 г. таких было в 2,5 раза больше - 24\% (Тюрюканова 2009: 292).

Как ни парадоксально, эти цифры говорят о большей интегрированности киргизов в российскую жизнь: теперь для всех перечисленных льгот не надо постоянно здесь жить, а кроме того, если что, всегда можно вернуться в Россию. Ситуация сказалось и на изменении творчества мигрантов, что хорошо прослеживается на примере той же А.Б. Бекболотовой: в её поэзии меньше собственно мигрантской тематики, хотя есть, безусловно, и она - вот для примера стихотворение «Поездка из Москвы». Поэтесса мечтает о возвращении на родину, вспоминает родных людей и любимый Иссык-Куль. На чужбине для неё всё иначе, приходится вставать ни свет, ни заря и «месить соль» на московских улицах.

\section{Москвадан сапар алдым}

Эл катары мен да кеткем иштөөгө, Москванын тузун таттым буюруп. Кызматчы да, башчы болдум иргебей, Чоң шаардын жашоосуна жуурулуп.

Таң заарда шашып жөнөп ишиме,

Кайра кайтам үрүл-бүрүл күүгүмдө. Күндөр сызып, өмүр өтүп билинбей, Жыл айланып, жөнөп жатам үйүмө.

Учуп көздөн алтын уям-өз үйүм,

Күн санаймын, сагынычтан кусамын. Кыялымда эчен жолу баргамын, Жыттап кызым, кучагыма кыскамын.

Алыс жерден сапар алып аттандым, Ысык-Көлүм, туулган жерге, мекенге. Урук-тууган, үй-бүлөмдү сагындым, Алып-учат, ойлор чубайт жеткенче.

\section{Поездка из Москвы}

Как и мой народ, поехал я в Москву

Месить московскую соль,

Был и рабочим, и начальником сортировки,

Вписался в жизнь большого города.

Встав ни свет, ни заря, отправлялся на работу, Возвращался в сумерках.

Дни прошли, время прошло незаметно, Год пролетел, и я еду домой.

Полётом мысли много раз видел родной дом, Дни считал, тосковал, Много раз был он в моих мечтах, Аромат любимой девушки, короткие объятия.

Приехал я издалека, Покинув родину - Иссык-Куль, Скучаю по родным, по семье, Пока мысли до них не дошли. 
Кере жуттум атыр жыттуу абаңдан,

Ой-кырларың, талаа-түзүң керилген.

Кубат алам илебинен көлүмдүн,

Берекелүү туулган жерим, демиңден.
Запахи, которые вы вдыхаете,

Поля, солончаки.

Силой мира веет от озера [Иссык-Куль].

Благословен рождённый от твоего дыхания.

Вообще, к занятию художественным творчеством А.Б. Бекболотову подтолкнуло в том числе, и ощущение несправедливости, выразившиеся в некоторых конкретных социальных явлениях. Например, в 2019 г. в Бишкеке в аэропорту она увидела старика, просящего милостыню, и это её задело (вообще, для тюркских народов старик, брошенный родными и просящий милостыню - это редкая и позорная аномалия), и пока ехала до Балыкчы (шесть часов на автобусе), написала стихотворение об этом.

\section{Каырычыга айланды}

Кай заманда калпак кийген карыя, Кайыр сурап отурчу эле көчөдө?

Кыргыз эли кылым атың татыган, Карыясын таштаганбы көчөгө? Кайыр сурап байбичеси олтурат, Кайсы бала бейиш төрүн таштады? Өткөндөрдөн тыйын сурап жалдырап, Ыйык эне тепсендиде калганы.

Ата-энеси кыргызымда кор болуп, Азап чегип көр окаттын айынан. Бак-дөөлөттүү карылыкты көрбөстөн, Зээниң кейит көздөрүнүн жашынан. Оомат келип кыргызымдын башына, Оңолсо экен бала-кыздын пейили. Карыялар акыл берип жаштарга, Байбичелер төргө отурсун кеңири.

\section{Становимся глухими}

Где старик в колпаке

Занимается попрошайничеством на улице?

Позор века киргизскому народу:

Старик вышел просить милостыню.

Попрошайничество убивает старушку,

Какой сын покинул её на это?

Просить копейки у прохожих?

Святая мать осталась, как выброшенная тобой выжимка.

Родители у киргизов стали униженными, Страдают из-за старости.

Жизнь без достойной старости,

Печаль от этих слёз.

Пришли для киргизов времена:

Дети не церемонятся,

Старики по уму ближе к молодым,

Бабушки могут сидеть в красном углу (?)

Были и другие, более широкие, касающиеся значительного числа людей явления - толчки для творчества, например, то, что в 2018 или 2019 гг. открыли урановые месторождения близ Балыкчы и собираются их разрабатывать, невзирая на предупреждения учёных, что это очень затронет местное население и весьма неблагоприятно скажется на экологии всего Прииссыккулья.

Более выгодное положение киргизов сказалось и на статусе их поэтов-мигрантов в России: 8 членов клуба «Московские напевы» стали (на начало лета 2021 г.) членами Союза писателей России, один получил Есенинскую премию. 29 марта 2021 г. приняли в Союз писателей России и А.Б. Бекболотову. Также она - член Союза российских поэтов (с ноября 2020 г.), некоторых других международных союзов, например, Международной Академии Российского Союза (МАРС) или Союза писателей.

На родине А.Б. Бекболотова с 2017 г. начала печатать стихи в Иссык-Кульской областной газете «Кол Деми». в 2019 г. на киргизском языке издана её книга «Ааламга жол» («Путь ко Вселенной»). Стихи её печатались на киргизском и русском языках также в газете «Маданият жана тил», в журналах «Аялзат», в сборнике стихов «Аалам жылдызы» («Звезда мира») киргизских писателей и поэтов в 2018 г., в антологии «Поэзия мигрантов» киргизских поэтов в 2021 г., в сборнике «Ааламга карай жол» в 2020 г., в сборнике «Ак калпак баяны» в 2019 г., в сборнике «Чынгызга таазим» 
в 2018 г., в России - в альманахах Союза писателей России, а также в международных альманахах: «Славянская лира» (Россия, Сербия, Болгария, Македония) - пять ра3, «Sun Sity» (Украина) три раза, «Чернильница» (Болгария), «Зимняя рапсодия» (Россия, Сербия, Македония),

Особо следует отметить творчество Жанны (Жамал Турдакуновны) Сабаевой - поэта, публициста, переводчика и общественного деятеля. Родилась Ж. Сабаева в 1966 г. в Иссык-Кульской области (Джеты-Огузский район, село Жон-Булак), в большой рабочей семье (восемь детей). в колхозе «Дружба», состоявшем из пяти сёл, жило несколько русских семей, с некоторыми из них семья Сабаевой дружила. Общение с ними привило хорошее знание русского языка, Жанна много читала, а в седьмом классе в школьной стенгазете опубликовала первое стихотворение. Позже, правда, лет тридцать особо не увлекалась творчеством: отвлекали учёба, работа, семейные заботы.

В 2005 г. Жанна переехала в Россию, в Кострому. И с тех пор жизнь самой Ж. Сабаевой и её семьи проходит в «треугольнике» Каракол - Москва - Кострома. в Чухломском районе Костромской области имеется купленный в 2007 г. сельский дом, выезд в который на лето, по её словам, очень способствует творческому вдохновению, ещё и благодаря хорошим соседям (её собственная характеристика: «истинно добрые и простые люди, мои преданные друзья и подруги»), и вообще, жизнь в этом загородном доме - «отдушина от всех жизненных человеческих проблем».

Здесь надо обратить внимание вот на что. Костромская область - один из депрессивных регионов, региональный долг которого примерно равен региональному бюджету. Растёт безработица, соответственно возрастает и отток местного населения. И трудовая миграция (неофициальная цифра которой, по некоторым сведениям, в 6-7 раз превышает официальную), например, в 2020 г. на 90\% компенсировала убыль населения в целом по РФ, в том числе дефицит врачей, учителей, инженеров, лиц со средним специальным образованием, работников обрабатывающей промышленности, а также сельского хозяйства (Белова 2021). Есть некоторые основания считать, что периодическое пребывание в таком регионе не могло не стимулировать социальную составляющую в творчестве Ж. Сабаевой.

Впрочем, творческое вдохновение, как уже сказано, вернулось к ней не сразу. Как и в случае с А. Имановой, определённым толчком послужили и свои проблемы со здоровьем: в 2012 г. она заболела раком (её оперировали более 16 часов). После болезни она снова начала писать статьи, а с 2014 г. - и стихи... И почти сразу на собрании литратурного клуба «Московские напевы» она была избрана редактором. в настоящее время Ж. Сабаева живёт и работает в Москве. Её основная работа - экспертный и синхронный переводчик с киргизского, казахского и узбекского языков на русский язык (и обратно) в следственных органах и судах Москвы и Московской области, со стажем более десяти лет. Когда через руки проходят такие материалы, то это тоже едва ли может не простимулировать социальную составляющую творчества.

Ж. Сабаева - активист, организатор первоначальных сборов и проведений акции «Бессмертный полк» в диаспоральных организациях в Москве и Московской области в 2014-2019 гг., сопредседатель Литературного Совета Ассамблеи народов Евразии, координатор литературного клуба «Москва кайрыктары» по Евразии, член национального Союза писателей Киргизской Республики и Московской областной организации Союза писателей России, правозащитница и юридический консультант по пра- 
вам детей и женщин - выходцев из Киргизской Республики; это лишь некоторые из её общественных нагрузок, на перечисление всех ушло бы несколько страниц.

Помимо всего прочего, она - автор стихотворного сборника «Сезим жаңырыгы», редактор сборников «Аалам жылдызы» («Звезда мира»), «Москва кайрыктары 5», переводчик книг с киргизского языка на русский и с русского на киргизский, член жюри литературных и международных культурно-массовых поэтических конкурсов и мастер-классов, литературный критик. Её произведения печатались не только в Киргизстане, России и других стран СНГ, но и в США. Вместе с тем, в творчестве Ж. Сабаевой преобладают иные мотивы, чем у А. Бекболотовой или А. Имановой, менее социально-острые. Например, в одном из стихотворений ощущается некоторая ностальгия по ушедшим временам (по молодости или по идеализируемым многими временам СССР - пусть каждый решает для себя).

\section{День, равный веку}

Мне б в самолёт, да полететь в страну,

Где безмятежно я жила когда-то.

И у тоски безвыходной в плену

Я лишь в душе туда стремилась свято.

Не раскрывала я своих секретов,

И чувств не раскрывала никому.

Но что-то изменилось в мире этом -

Смеюсь, сама не зная почему.
Что время? Время не подвластно людям, Года летят, как в небе стая птиц.

Сказал Чынгыз: «Любовь должна быть чудом, Костёр любви не требует границ».

Сакральность этих высказанных слов,

Ведут по жизни, отмечая вехи.

Я жду тот день, как жду свою любовь,

И этот новый день подобен будет веку.

А вот стихотворение «Привет, Москва!» - в нём поднимается такая тема, как положение киргизов в России. По словам автора, они, несмотря на распад СССР, в последние годы чужаками себя здесь не чувствуют. Кстати, А.Б. Бекболотова хочет в России купить земельный участок, что не говорит однозначно о стремлении закрепиться в России на ПМЖ (старшая её дочь живёт в США, младшая сестра в Австрии), но при этом налицо некое особое отношение к столице России: «Москва для нас - как «центр Вселенной», я с детства стремилась к Москве». А Ж. Сабаева пишет, что она берёт силы от «мощной матери Москвы, она для неё «надежный оплот», «святая и драгоценная».

\section{Привет, Москва!}

Привет, Москва, пришла обратно, обними меня, Соскучилась, добрые желания шлю тебе.

Ты свидетель прошлых тех годов, Есть ли тайны, скрываемые от меня? Обучила, изучила историю мою, Воспитала как добиться цели своей. При наблюдении, неверные шаги, Не медля, ты нашла другие пути. Слышишь меня, когда плачу и пою, Дашь благо, делив внимание своё. Как родная, духовно и благородно, Поднимешь гордо, увяданию закрыв дорогу.
Беру силы от мощной матери Москвы, Любуюсь в удовольствие сточными водами реки,

Ты мне надёжный оплот, не забуду навеки, Святая, драгоценная, мне дороги ласки твои. Не делишь, откуда и от какого народа, В достатке живём, трудясь и любя. Поровну делим радости и печали, Настанет время, напомнишь о себе... Расти, цвети, богатя историей любви, Не дай печалиться, прогони тоску. Поднимусь и выше, буду ещё смелей, Стану величаво, ведь обучала меня ты. 
Отметим, что некоторые поэты-мигранты посвящают подобные стихи и другим российским городам, где им удалось найти место в жизни. Например, Асан Тынаров, 1997 г.р., уроженец Аксыйского района Джалал-Абадской области, работает в Новосибирске (Москва кайрыктары-6 2016: 312).

\section{Новосибирск}

Онго-солго болунгон шаарды кордум,

Ойго салат чынында далее кобун.

Ортосунда токтобой агып жаткан,

Обь суусу ачып турат анын коркун. Билгин келсе айтайын шаардын озун, Билбегенге табышмак жазган созум.

Кен Сибирдин борборунан орун алган, «Новосибирск» - деп аталат ошол торум. Новосибирск жашоо бердин копторуно,

Сыйкырын бар соз жеткис коркомундо.

Сен жайган кучагынды данктап бугун, Айткым келди эп корсон создорумдо. Кун сайын жаныланап мээнеттерден, Коп улуттун башын коштун эмгек менен. Эл наркын тушуно алган мамилен бар,

Коркомуно башка шаарлар эч жетпеген.

Оркундоп-осо бергин, айтаар кебим, Келеченин кен болсун шаарым менин. Кучагынды келгендерге кенен акчын, Новосибирск-энчиде болуп элдин.

\section{Новосибирск}

Я видел город, разделённый направо и налево, На самом деле это всё одно.

Непрерывный поток между [половинами] Вода Оби раскрывает её красоту.

Если вы хотите знать особость города, Написанное мной - ответ для незнающего. Место расположено в центре Сибири, «Новосибирск» называется оно.

Новосибирск даёт нам много жизни (возможностей? - Г.С.),

Но в этих словах нет ничего волшебного.

Слава твоим распростёртым объятиям,

Как, видите вы, хотел я сказать.

Обновляется каждый день

Трудом многих наций.

У вас есть отношения, которые люди ценят, Достопримечательности не уступают другим городам.

Я бы сказал, процветать

Пусть мой город будет больше.

Широко открытый для гостей,

Новосибирск - достояние народа.

Организаторы клуба «Московские напевы» «следуют пути Ч.Т. Айтматова», считают, что надо заниматься культурой, а не политикой». Совсем без политики, однако, не получается: расхожее выражение «не хотите заниматься политикой - политика займётся вами» актуально и для киргизов-мигрантов. Да и всегда ли можно отделить социальное - все эти описанные уже проблемы, в своей ли стране, в России ли или в третьей стране - от политики?

Ж. Сабаева говорила мне: «Я хочу, чтобы люди всей планеты жили в мире и согласии, для того чтобы прочно существовал мир и дружба, чтобы они много читали и духовно, нравственно развивались, соблюдали права и обязанности, простые элементарные правила. Вот тогда не будет ненависти, разногласий и международных столкновений». С этими мотивами перекликается и стихотворение Бурмакан Тургунбаевой 1977 г.р., уроженки Кара-Сууского района Ошской области, по основной специальности - учительницы химии и биологии (Москва кайрыктары-5 2016: 91).

\section{Адам бойдон жашайылчы}

Адам бойдон жашайылчы, адам бойдон, Жаныдан баштайылчы кадам коюп.

\section{Пусть человек живёт вечно}

Пусть человек живёт вечно, пусть живёт, Шаг за шагом, чтобы начать все сначала 
Жамандык ойлобостон эч бир жанга, Жашалга ар биринер таза бойдон!

Адам бойдон жашайылчы, адам бойдон,

Озгоруп кетпегиле наадан болуп.

Жашоого бир келебиз, кетебиз да,

Убактылуу биз мында мейман болуп.

Адам бойдон жашайылчы, адам бойдон!
Ни одна душа не думает о зле,

Пусть каждый из вас будет чист!

Пусть человек живёт вечно, пусть живёт,

Не становись глупее.

Один раз приходим мы в жизнь и один раз уходим,

Мы здесь временно, в гостях.

Пусть человек живёт вечно, пусть живёт!

А.Б. Бекболотова писала, как говорилось выше, об урановых рудниках в Балыкчы - можно ли сказать, что эта тематика не имеет отношения к политике? А вот уже однозначно политика: под впечатлением недавнего (весна 2021 г.) конфликта между киргизами и таджиками она же написала новое стихотворение.

\section{Биз үндөйлү}

Ынтымакта жашап келген коңшу элдер,

Аркы өйүз, берки өйүз суудан ичип.

Алла берген бир насиптен даам татып,

Бир-бирине сыйын арткан кыргыз, тажик.

Бейпил жаткан эзелтеден кошуналар,

Ортодо чагымчылдар от таштады.

Ок атылып шейит кетти азаматтар,

Үй-бүлөлөр наалат айтып зар какшады.

Душмандар бар арабызда калп корсулдап,

Карап турат маашырлана жик өткөрүп.

Кылым карытчуу кыргыз, тажик коңшу эли,

Касташпайлы бузуку үчүн өпкөөрүп.

Куран окулсун шейит кеткен маркумдарга,

Кайрат тилейли бир тууган, үй-бүлөгө,

Манастын эр жүрөктүү урпактарына,

Сурайлы бейишин берсин Алла Таала.

Кыргызды кыргыз кылган сабырдуулук,

Ак сакалдын сөзүн угуп

кадырлайлы.

Эки эл кошуна болот түбөлүккө,

Кызыл кандуу ачуулука алдырбайлы.

Илгертеден «Кан кетирбейт»-деген калган,

Тынчтыкты сакташ үчүн күчтү үрөйлү.

Бузуку учур келсе энчисин алат,

Эки элди ынтымакка биз үндөйлү.

\section{Будем едины}

В мире и согласии живут два народа, Чистой воды обоим соседям хватает. Насладитесь дарами, что дали Аллах и природа.

Кыргыз и таджик друг друга всегда уважают. С древних времён крови не проливали, Смутьяны меж ними огонь разожгли. Простые граждане погибли и пострадали, Родные, крича проклятия послали свои.

Меж нами вражду посеяли змеи, Не будьте пешками в их руках.

Кыргызы, таджики будьте мудрее, А подлецам воздастся на небесах.

По погибшим прочитают Коран, Братья, родные мужества вам пожелаю, Потомки Манаса развеют злобы туман, Всевышний Аллах откроет дорогу к раю. Кыргыза кыргыз убереги от гнева, суда, Совет Аксакала послушаем дорогие мои. Ведь два народа соседи навек, навсегда, Затушим огонь злобы в нашей крови.

Придёт время виновным за зло отвечать, Зачем же напрасно кровь проливать? Давайте хрупкий мир мы сбережём, К единству два народа призовём.

Таким образом, политическая составляющая в ее поэзии свелась к призывам жить дружно, как и веками раньше жили. в целом же, как мы видим, социальное творчество представлено не только (а после введения в 2018 г. упомянутых льгот для киргизов - и не столько) в связи с проблемами мигрантов в России, но и с проблемами на родине, включая положение в стране в целом.

Из сказанного не следует, что последний мотив не встречался в творчестве мигрантов и до 2018 г. Вот для примера стихотворение Гюльджан Жантороевой (1979 г.р., уроженки Сузакского района Джалал-Абадской области, члена творческого объ- 
единения «Эргун», с 2017 г. - активистки киргизской диаспоры в Москве, члена общественного совета) с достаточно привычным уже названием «Песня мигранта». в нём уже заметен переход от обычных забот, мечтаний, чаяний мигранта в чужой стране к проблемам страны родной, завершающееся призывом не просто после работы в России заняться обустройством Киргизстана, как в стихотворении Муамбета Каныбек уулу, но объединиться и думать о стране (Москва кайрыктары-6 2017: 63).

Жашоодо мигранттын жолун баштап, Ар олкодо журобуз жолун таштап. Таркалып бир ууч кыргыз туш тарапка, Жакшыртам деп жашого кадам таштап.

Ала-Тоо мекенинен алыс кетип, Эки аяк ат баспаган жерге жетип. Ар-намысты, мекенди коргой албай, Акча учун кетишти кобу тентип.

Ар-намыстуу эр жигит торолобу, Кыргызды кыргыз кылып кармап турган. Алыска акча учун билдирбестен, Кыргыз учун жан аябай куйуп-жанган.

Кыргызым, айтчы, жашоон онолобу, Же акча деп ар кай жерде жоголобу? Кен байлык баары бизде толуп турса, Жок кылчу ойрондорун торолобу.

Таркалайбы, кол кыргызым, биригели, Озду эмес, ойлойлучу жалпы элди. Бейиштей берекелуу кымбат бизге, Ала-Тоо мекенемдин сулуу жери.

Жараткан тартуу кылган бейиш жерин, Ботонго борулордой тепсетпегин. Данктайлы, ардактайлы ар бир жаран, Олконун туусу бийик желберисин.
Начиная путь мигранта,

Оставляешь свой след в каждой стране.

Горстка рассеянных киргизов

идёт по разным местам,

Чтобы сделать жизнь лучше.

Вдали от родного Ала-Тоо

Добравшись «на своих двоих»,

Не сумев защитить честь и родину,

Многие скитались за деньгами.

Родился ли достойный мужчина,

Чтобы киргиз остался киргизом.

Не только ради денег,

Но и ради киргизов.

Скажи мне, друг мой киргиз, жизнь наладится

Или по всей [нашей] земле деньги пропадут?

Пусть богатство будет в нашей земле,

Пусть не рождаются те, кто уничтожает.

Киргизы, давайте объединимся, Будем думать не о себе, о народе.

Как в раю хорошо,

Родную землю Ала-Тоо обустроим.

Пусть не потрясает райскую землю, Подаренную Всевышним, чужая буря.

Пусть каждый гражданин будет славен и уважаем,

Пусть высоко будет поднято знамя страны.

В таком же духе написано и стихотворение С.Б. Насыровой «Соотечественники» (приводится частично). Автор переживает, что её соотечественникам приходится «гробить себя», «работать на износ».

\section{Мекендештер}

Булуттан, мелт калт этип төгүлчүдөй, Буулугуп, кең дүйнөгө батпай турам. Бузулуп, жыты келип батыш жактын, Бул күндө нагыз кыргыз таппай турам...

Жогортон бийлик, байлык талашышат, Мансапка чоңдорубуз жанын кыят. Кыдырып кеткен элдин тагдырычы, Кыргызды чачыраган кимдер жыят?..

\section{Соотечественники}

Из туч льётся дождь, Я задыхаюсь и не вписываюсь в мир, Он портится под влиянием Запада, Я не могу найти настоящего киргиза.

Наверху - борьба за власть и богатство, Многие гробят себя ради карьеры. Судьба народа, который это прошёл Собирать мусор? 
Жаш кыздар тырбалаңдап иштеп жатат, Мектепти кечээ гана келген бүтүп. Идиш жууйт үй жыйнайт, бала багат, Иштейт деп ата-энеси калган күтүп.

Убакыт зымырык куш сызып барат, Урпактар пейил куйун бузуп барат. Ууланып бузулгандай бул замана, Уланбай күндөн күнгө кысып барат...
Молодые девушки работают на износ, Только закончив школу.

Мытьё посуды, уборка, уход за ребёнком, Другим родителям тоже это предстоит.

Время царапает как наждачная бумага, Портится потомство.

Это отравленное время,

Не поддавайся ему изо дня в день.

В то же время, когда С.Б. Насырова стала более профессионально заниматься поэзией, в её творчестве собственно мигрантская тематика сменилась более общими, философскими проблемами - например, в стихотворении «Ой толгоо» («Мысли крутятся [в голове]») она размышляет о быстротечности жизни (Москва кайрыктары-6 2017: 188).

А вот стихотворение Канатбека Жапара, 1986 г.р., из г. Сулюкта Ошской области (Москва кайрыктары-5 2016: 220), в котором не просто указывается на социальные проблемы в родной стране, но и говорится о конкретных виновниках этих проблем - о правящей верхушке.

\section{Тоболдорго}

Аранарда адилеттуу жан барбы? Апчыйсынар алты нолдуу сандарды.

Карапайым калк жадады, жудоду, Тосо берип бурганактуу тандарды.

Жыланайлак жарды було кобойду. Жарды эмне, же отукчон торойбу? Эркелетип, эрезиге жеткирип, Ээлик берген эл силерге огойбу?! Кочо тенткен жетим-жесер кобойду. Кочо эмне, мээримине болойбу? Бата берип, бетинерден суйушуп, Ат мингизген эл силерге огойбу? Корконнум бар, кор болот го урпактар, Минтип силер отурганда ууртап бал!

Оо, Тенирим! Берчи Барсбек, Манасты! Ордобузду бийлеп калды куурчактар! Корконнум бар, соолуп барат Мекеним. Кошуналар койбойт шекер бекерин. Оо, тоболдор! Корсоткуло эл-журтка, Барсбек, Манас учурда бар экенин! Аранарда адилеттуу жан барбы? Апчыйсынар алты нолдуу сандарды.

Айла таппай калк жадады, жудоду, Айдай берип хан артында хандарды.

\section{Верхушке (Правящей элите)}

Есть ли среди вас справедливая душа? Угадай шесть нулевых чисел (м.б. «догадайся с трёх раз»? - Г.С.). Народ устал, Посеешь ветер - пожнёшь бурю (букв «Метель, дающая метель»). Разутой выросла бедная семья. Что родит бедняк или сапожник? Люди, которые вас холят, растят И дают вам богатство, скверные дети! Уличные бродяги, сироты-вдовы. Что такое улица?

Народ, который полюбил вас И посадил во власть, пасынок для вас? Боюсь, потомство может пострадать, Так что наслаждайтесь жизнью, пока у власти! (букв.: «Так что глотайте мёд, пока вы сидите!» О, Господь! Дай Барсбека, Манаса!

Сейчас у нас куклы верховодят!

Опасаюсь, что моя Родина гибнет.

Соседи не любят сахар.

O, правители! Покажите народу, Барсбека, что в случае с Манасом! Есть ли среди вас справедливая душа? Угадай шесть нулевых чисел (м.б. «догадайся с трёх раз»? - Г.С.).

Население в отчаянии, Пустыня остаётся позади ханов (?). 
А вот призыв уже не просто объединиться (тем более не просто обличение виновников социальной несправедливости), но «проснуться» - такое стихотворение написал Олжас Садыбеков, 1979 г.р., уроженец Тюпского района Иссык-Кульской области (Москва кайрыктары-6 2017: 245).

\section{Ойгон, Кыргыз!}

Ойгон Кыргыз, айтар созум, милдетим,

Ким которот, элдин жугун, илдетин? Курчап турат ажыдаарын баштары, Ойлой-ойлой конулумду кирдеттим. Калпак кийим тушунбосум неге мен, Башка олкодон, оо, эл-журтум эмнен кем? Бейишиндей жерин турат колдолуп,

Болунбойлу бироолорго болуп жем. Тушун, ойлон, кыргыз атын теренден,

Коркуп турам озгодон муш жегенден. Бириге албай чачырады элибиз, Кудай сакта, манкурт болду дегенден. Нечен жолу башты ийдик, ийилдик, Кооз суйлоп, туркун кийим кийиндик. Эми ойлон, калын журтум тике тур, Экиге эмес, беш-алтыга тилиндик. Кырван Манас кайдан чыккан эстейли, Чалчык сууну кайра-кайра кечпейли. Бир муштумдай биригели Кыргызым, Жараткандан дуба кылып тилейли.

Мекенибиз калды такыр каралбай, Жер сатылып, мурастары бааланбай. Кендерибиз казылганы казылган, Чек арабыз турат бир да такталбай.

\section{Проснись, киргиз!}

Проснись, киргиз, твой долг - сказать слово,

Кто же понесёт бремя народа?

Вокруг головы дракона,

Я много думал об этом.

Почему я ношу шляпу

Из другой страны, о мой народ?

Происходит надругательство над райской землёй

По принципу «Разделяй и властвуй».

Так что думай, вспомни, что имя тебе киргиз, Не испытывай ложной боязни.

Народ, который не может объединиться,

По воле Бога превращается в манкурта.

Сколько раз мы склоняли голову,

Говорили красиво и красиво одевались.

А теперь надо распрямиться,

Мы на языке 5-ти или 6-ти, а не двух (?)

Помните, откуда появился Манас,

Снова и снова не пропускайте воду (?).

Давайте соберёмся в кулак,

И будем просить Всевышнего [о помощи].

Без оглядки на нашу родину

Земля продана, наследие не ценится.

Добыча полезных ископаемых

[за границу уходит] -

У нас нет чётких границ.

И последнее, ещё более радикальное стихотворение - «Партия», автор его - Элиана Усенбек Кызы, 1988 г.р., из Таласского района Таласской области; в Москве работает флористом-дизайнером (Москва кайрыктары-5 2016: 344). Под «партией», возможно, по советской привычке (впрочем, странной для столь молодого автора), подразумевается «номенклатура».

\section{Партия}

Бийлик дешип кызмат кылбай калкыма, Власти бесцеремонно лгут, Бири даргы турбай берген антына. Кымындай да ар-намысы калбаган

Кыйнады го кыргызынды ПАРТИЯ! Ишендирип элди куру калпына, Ичин сылап жатат озу мантыга. Итке окшоп тоюшканын билишпей, Ичип-жеди баарын ушу ПАРТИЯ! Чек аралар, жашыл жайлоо Каркыра,

\section{Партия}

Клянясь, что ни один из них не отступится (от обещаний? - Г.С.).

Ни в малейшей степени честь и достоинство Не мешают партиям мучить киргизов!

Обирая народ,

Он поглощает это в себя.

Не зная, что их (людей? - Г.С.) кормят, как собаку,

Партия выпила и съела это всё! 
Сатылды го кытай, тажик, сартына.

Чыт курсагын ойлобогон Жан барбы,

Чындап куйгон элибиздин баркына.

Кокурокто коодунун бош болбосо,

Кошул анда сап бололук камчыга.

Келечекти сатпай бугун акчага,

Кел саталык кереги жок ПАРТИЯ!
Партия выпила и съела это всё!

Зелёные летние пастбища на Каркыре

Продаются китайцам, таджикам, узбекам.

Есть ли душа, которая не думает о брюхе,

Люди, которые действительно переживают

(за страну - Г.С.)?

Если грудь не может вздохнуть свободно,

Употреби власть.

Не продавая будущее за деньги,

Не пускай [к власти] ПАРТИЮ!

Связано творчество киргизов-мигрантов и с социальными проблемами чисто российскими, но, поскольку мне удалось найти на эти темы только прозу, то я этот аспект мигрантского творчества пропускаю.

Общие выводы по теме исследования можно сделать такие:

в творчестве киргизских поэтов-гастарбайтеров по мере улучшения их положения постепенно сокращается тематика чисто мигрантских проблем;

одновременно возрастает осознание важности социальных вопросов своей страны - от мечтаний о том, как после работы в России они станут «украшать» и свою страну - к значительно более социально острой тематике, вплоть до достаточно радикального обличения жизненных сложностей и их виновников, призывов «проснуться»;

появляются и творческие произведения о социальных проблемах принимающей страны (например, рассказ А.Б. Бекболотовой «Домовой в метро», который, однако, как прозаическое произведение здесь приводиться не будет); очевидно, это связано с большей интегрированностью киргизов в Россию - как я уже писал, после 2018 г. они чувствуют себя «как дома или почти как дома»;

вероятно, с более тесной интегрированностью киргизов в Россию связано и то обстоятельство, что творчество некоторых авторов касается особого отношения к Москве, к некоторым другим городам, к России в целом;

наконец, надо отметить, что чем бо́льшим профессионалом является автор (особенно это заметно на примере творчества А.Б. Бекболотовой, отчасти С.Б. Насыровой), тем меньшее место в его творчестве занимает собственно мигрантская тематика, тогда как удельный вес более общих проблем возрастают.

\section{Источники и материалы}

Киргизы Москвы - Киргизы Москвы: работать на своих и со своими. https://krg.rus4all.ru/ city_msk/20170914/728325610.html.

Перспективы кыргызской - Перспективы кыргызской диаспоры в России. http://www. region.kg/index.php?option=com_content\&view $=$ article $\&$ id $=2435: 2017-08-04-04-24$ $16 \&$ catid $=5$ :obshestvo\&Itemid $=6$.

Почему киргизы - Почему киргизы живут на две семьи. https://moslenta.ru/city/kyrgyzstan.htm (20 августа ****).

Аттокуров 2009 - Аттокуров Р. Традиция омичей помогать друзьям// Право на выбор. Журнал избирательной комиссии Омской области. 2009. № 2 (17). С.18-19.

Москва кайрыктары-5 2016 - Москва кайрыктары-5. Бишкек, 2016.

Москва кайрыктары-6 2017 - Москва кайрыктары-6. Бишкек, 2017.

Сафонов 2008 - Сафонов Я. Кыргыз-таун на Сахалине: миф или реальность? // Советский Сахалин. 23 апреля 2008. 


\section{Научная литература}

Белова Н.А. Отношение россиян к мигрантам (на примере Костромской области) // XIV Конгресс антропологов и этнологов России. Томск, 2021.

Вешкурова А.Б. Регулирование процессов внешней трудовой миграции из стран Центральной Азии в РФ и Казахстан. Дисс... к.э.н. М., 2011.

Маметов Р.A. Кыргызская Республика: анализ состояния современных миграционных потоков с учётом мирового финансового кризиса // Материалы студенческой конференции «Проблемы миграции населения в условиях финансово-экономического кризиса». М., 2009. C. 46-49.

Мендибаев Н. Бедность как основной фактор миграции населения Кыргызстана// Проблема бедности и богатства в контексте концепции державности. Материалы международной научно-практической конференции. Тамбов, 2012. С. 113-117.

Ситнянский Г.Ю., Бушков В.И. Миграции населения в Центральной Азии: прошлое, настоящее и будущее. М., 2016.

Ситнянский Г.Ю. Киргизы в России: «как дома» или «почти как дома»? // Среднеазиатские диаспоры в России: пересечение идентичностей и взаимодействие с постсоветскими государствами. М.: ИЭА РАН, 2018. С. 86-97.

Тюрюканова E.B. Управление трудовой миграцией: долгосрочные тенденции и оперативные решения// Миграции в современной России: состояние, проблемы, тенденции. М., 2009. C. 284-293.

Sitnyansky, Georgy Yu.

\section{Current Issues of Social Justice Reflected in the Poetry of Kyrgyz Labor Migrants in Moscow}

\section{DOI: $10.33876 / 2311-0546 / 2021-4 / 129-148$}

Kyrgyz labor migrants in Russia are in a better situation than representatives of other Central Asian countries both in terms of more qualified work and cultural and linguistic integration into Russian society. Thus they have more opportunities not only for artistic creativity in verse and in prose but also for a closer interaction with Russian literary organizations. For example, a considerable part of the Kyrgyz migrant literary club "Moscow Melodies" closely interact with the Union of Writers of Russia and other literary organizations, up to membership in them.

The article examines the poetry of some of the most outstanding representatives of the Kyrgyz diaspora. The poems are devoted to a variety of issues: the problems of migrants themselves and many topical social problems at home, from domestic violence to uranium mining and interethnic conflicts. It should be noted that the nature of Kyrgyz poets'creativity has gradually changed, from the predominance of purely migrant problems to more general issues of social justice, primarily in their own country, especially after Kyrgyz guest workers received some benefits compared to other labor migrants in 2018.

Keywords: Kyrgyz migrants, Moscow, creativity, poetry, social justice.

For Citation: Sitnyansky, G.Yu. Current Issues of Social Justice Reflected in the Poetry of Kyrgyz Labor Migrants in Moscow. Herald of Anthropology (Vestnik Antropologii) 4: 129-148.

Author Info: Sitnyansky, Georgy Yu. - PhD in Hist., Senior Researcher, Institute of Ethnology and Anthropology of the Russian Academy of Sciences (32-A Leninsky Prospekt, Moscow, 117334). E-mail: sitnyan@mail.ru 
Funding: The study was carried out with the financial support of Rosa Luxemburg Foundation Branch in RF within the topic "Social Justice in the Poetry of Migrant Workers from Central Asia in Russia".

\section{References}

Belova, N.A. 2021. Otnosheniye rossiyan k migrantam (na primere Kostromskoi oblasti) [The attitude of Russians to migrants (on the example of the Kostroma region)] In XIV Kongress antropologov $i$ etnologov Rossii [XIV Congress of anthropologists and ethnologists of Russia]. Tomsk.

Mametov, R.A. 2009. Kyrgyzskaya Respublika: analiz sostoyaniya sovremennyh migratsionnyh potokov s uchetom mirovogo finansovogo krizisa [Kyrgyz Republic: analysis of the state of modern migration flows taking into account the global financial crisis] In Materialy studencheskoi konferentsii "Problemy migratsii naseleniya v usloviyah finansovo-ekonomicheskogo krizisa [Materials of the student conference "Problems of population migration in the conditions of financial and economic crisis], 46-49. Moscow.

Mendibaev, N. 2012. Bednost' kak osnovnoi fartor migratsii naseleniya Kyrgyzstana [Poverty as the main factor of migration of the population of Kyrgyzstan] In Problema bednosti I bogatstva $v$ kontekste kontseptsii derzhavnosti. Materialy mezhdunarodnoi nauchno-prakticheskoi konferentsii [The problem of poverty and wealth in the context of the concept of statehood. Materials of the international scientific and practical conference], 113-117. Tambov.

Sitnyanskiy, G.Yu., and V.I. Bushkov 2016. Migratsii naseleniya v Tsentral'noi Azii: proshloe, nastoyaschee $i$ buduschee [Population migration in Central Asia: Past, present and future]. Moscow.

Sitnyanskiy, G.Yu. 2018. Kirgizy v Rossii: kak doma ili pochi kak doma? [Kyrgyz in Russia: "like at home" or "almost like at home"?] In Sredneaziatskiye diaspory v Rossii: peresechenie identichnostei I vzaimodeistvie s postsovetskimi gosudarstvami [Central Asian Diasporas in Russia: the intersection of identities and interaction with Post-Soviet states], 86-97. Moscow: Institute of Ethnology and Anthropology RAS.

Tyuryukanova E.V. 2009. Upravlenie trudovoi migratsiyei: dolgosrochnye tendentsii I operativnye resheniya [Labor migration management: long-term trends and operational solutions] In Migratsii v sovremennoi Rossii: sostoyanie, problemy, tendentsii [Migration in modern Russia: status, problems, trends], 284-292. Moscow.

Veshkurova, A.B. 2011. Regulirovanie processov vneshnei trudovoi migratsii iz stran Tsentral'noi Azii v Rossijskoj Federacii I Kazahstane. Dissertation [Regulation of the processes of external labor migration from Central Asian countries to the Russian Federation and Kazakhstan]. 